\title{
Potensi Arang Aktif dari Kulit Buah Durian (Durio Zibethinus Murr.) dengan Aktivator NaOH sebagai Penjernih Air Sumur
}

\section{Potency of activated carbon from durian fruit skin (Durio zibethinus Murr.) with $\mathrm{NaOH}$ as activator in purifying water well}

\author{
Jevon Aristo Pascal Budiman ${ }^{1 *}$, Indah Murwani Yulianti ${ }^{1}$, Wibowo Nugroho Jati ${ }^{1}$ \\ ${ }^{1}$ Program Studi Biologi, Fakultas Teknobiologi, Universitas Atma Jaya Yogyakarta, Yogyakarta \\ Email: Jevonaristo21@gmail.com *Penulis untuk korespondensi
}

\begin{abstract}
Water in some areas has poor quality so that the continuous consumption can lead to several waterborne diseases including diarrhea, dysentery and cholera. This problem can be prevented by using the activated carbon filter. Skin waste of durian can be processed into activated carbon to improve water quality. This research was conducted by using a completely randomized factorial design with various concentration of $\mathrm{NaOH}(25 \%, 30 \%$, and $35 \%)$ and time variance (20, 40 and 60 minutes). The best result was obtained from $35 \%$ of $\mathrm{NaOH}$ in 60 minutes with the decrease of turbidity by $95.48 \%$, TDS by $29 \%$, iron content by $87 \%$, water hardness by $71.8 \%$, and total coliform from $24 \mathrm{MPN} / 100 \mathrm{ml}$ to $0.1 \mathrm{MPN} / 100 \mathrm{ml}$.
\end{abstract}

Keywords: Activated Carbon, Durian Peel, Metal Ion Fe, Water Hardness

Abstrak

Air di beberapa daerah memiliki kualitas yang buruk, sehingga bila dikonsumsi terus-menerus dapat menyebabkan berbagai penyakit seperti diare, disentri dan kolera, namun dampak tersebut dapat dicegah dengan metode filtrasi arang aktif. Limbah kulit durian dapat diolah menjadi arang aktif yang dapat digunakan untuk meningkatkan kualitas air.Penelitian ini menggunakan rancangan acak lengkap (RAL) faktorial dengan variasi penambahan konsentrasi $(25 \%, 30 \%$, dan $35 \%)$ dari bahan aktivasi $\mathrm{NaOH}$ dan waktu yang dibutuhkan (20, 40 dan 60 menit). Hasil terbaik diperoleh dari arang yang di aktivasi dengan $\mathrm{NaOH} 35 \%$ dalam kontak waktu selama 60 menit. Terjadi penurunan angka kekeruhan sebesar 95,48\%, TDS sebesar 29\%, kandungan logam Fe sebesar 87\%, kesadahan sebesar 71,80\%, dan tingkat koliform dari 24 MPN/100ml menjadi 0,1 MPN/100 ml.

Kata kunci: Arang aktif, kulit durian, logam Fe, Kesadahan

Diterima: 25 Juli 2018 , disetujui: 30 Agustus 2018

\section{Pendahuluan}

Air merupakan hal penting yang tidak bisa dipisahkan dalam kehidupan sehari-hari. Terdapat berbagai sumber air seperti air permukaan, air tanah, dan air hujan. Namun, tidak semua air layak untuk dikonsumsi dan digunakan, sebagai contoh adalah air yang sudah tercemar sehingga mengandung banyak mikroorganisme (koliform) yang merugikan bagi manusia. Selain mikroorganisme, terkadang air dapat mengandung bahan beracun seperti besi (Fe), timbal ( $\mathrm{Pb})$, merkuri (Hg) yang membahayakan kesehatan (Untung, 2008).
Penurunan kualitas air dapat juga terjadi dikarenakan penyemprotan pestisida, bebatuan kapur (Dantje dan Sembel, 2015). Pentingnya kebersihan air menyebabkan beberapa hal perlu diperhatikan. Pada umumnya standarisasi dari air untuk keperluan higiene sanitasi meliputi parameter fisik, biologi, dan kimia. Air tersebut biasanya digunakan untuk kepentingan pemeliharaan kebersihan perorangan seperti mandi, cuci peralatan dan sebagai air minum (Menkes, 2017). 
Pada air di dalam tanah (air sumur), kadar $\mathrm{Fe}$ dapat jauh lebih tinggi, hal ini disebabkan oleh unsur besi di air tanah. Konsentrasi besi pada tanah pun beragam antara $0,01 \mathrm{ml} / 1$ hingga $25 \mathrm{mg} / \mathrm{l}$. Pada umumnya kesadahan merupakan parameter untuk kualitas air bersih karena menunjukkan ukuran mineral di dalam air. Kandungan $\mathrm{Ca}$ yang berlebihan akan menyebabkan tingkat kesadahan air tinggi. Apabila manusia mengonsumsi air sadah, akan menimbulkan berbagai macam panyakit seperti penyakit pada ginjal (Asmaningrum dan Pasaribu, 2016).

Proses penghilangan logam berat dari lingkungan tercemar sering kali menggunakan metode adsorpsi. Metode ini efektif menghilangkan logam berat walau hanya dilakukan dengan proses adsorpsi yang relatif sederhana (Marlinawati dkk., 2015). Arang aktif menggunakan prinsip dan mekanisme dari adsorpsi.Arang aktif adalah suatu karbon yang punya kemampuan daya serap yang bagus dalam larutan maupun gas terhadap anion, kation, dan molekul dalam bentuk senyawa organik dan anorganik. Pada permukaan arang biasa masih ditutupi oleh deposit hidrokarbon yang menghambat keaktifannya, sedangkan pada arang aktif permukaan relatif bebas dari deposit, permukaan luas dan pori-pori telah terbuka, sehingga memiliki daya serap tinggi. Pengubahan arang biasa menjadi arang aktif dengan melalui proses aktivasi (Lempang, 2014). Bahan baku arang dapat berasal dari tumbuhtumbuhan, limbah atau mineral yang mengandung karbon dapat dibuat menjadi karbon aktif (Marlinawati dkk., 2015).

Durian (Durio zibethinus Murr.) adalah tanaman buah asli Asia Tenggara yang tingkat keanekaragaman tertinggi berada di Borneo (Sobir dan Rodame, 2010). Produksi buah durian dapat mencapai \pm 38 ton per tahun (Rodame dkk. 2010). Pada kulit durian memiliki kandungan selulosa terbanyak yaitu sekitar lignin $5 \%$ dan $50 \%$ - 60\% carboxymethylcellulose. Tingginya kandungan karbon pada kulit durian menyebabkan adanya kemungkinan mengubah kulit durian menjadi produk yang lebih berguna sebagai contoh arang aktif (Noer dkk., 2015).

Banyaknya jumlah kulit durian yang tidak diolah dengan baik dapat menjadi sumber penyakit. Oleh karena itu, perlu disikapi dengan mengolah limbah kulit durian sehingga memiliki nilai ekonomi dan dapat berguna. Peneliti tertarik untuk memanfaatkan kulit durian yang diolah menjadi arang aktif untuk menjernihkan air sumur.

\section{Metode Penelitian}

\section{Bahan dan Alat}

Bahan yang digunakan adalah kulit durian, $\mathrm{NaOH}$, sampel air (air sebuah sumur dari daerah Banguntapan Yogyakarta), aquades, medium lactose broth, indikator phenol red, Brilliant green bile, Eosin Methylene Blue Agar, Pereaksi $\mathrm{Fe}$, indikator EBT, KCN, alkohol, Buffer $\mathrm{pH} 10$, $\mathrm{Na}_{2} \mathrm{~S}_{2} \mathrm{O}_{3}$, serta larutan ethylene diamine tetra asestat (EDTA) 0,01M.

Alat yang digunakan adalah oven, tanur (furnace), peralatan penggiling, gelas porselin, wadah keramik, timbangan, pengaduk, ember, botol, pisau, desikator, TDS meter, termometer, turbidimeter, stopwatch, alat pengayak ukuran mash 70, vortex, cawan petri, propipet, pipet ukur, gelas ukur, $\mathrm{pH}$ meter, buret, statif, kapas, tissue, aluminium foil, kertas saring, tip, tabung reaksi, tabung Durham, rak tabung reaksi, bunsen, korek api, pipet tetes, erlenmeyer, Fe kit, petridish, laminar air flow (LAF321), incubator, ose, gelas benda, kamera, dan plastik wrap.

\section{Preparasi Sampel}

Kulit durian yang akan dikarbonisasi, terlebih dahulu dibersihkan, lalu dikecilkan ukurannya menjadi $\pm 2 \mathrm{~cm}$. Kemudian dikeringkan mengunakan oven dengan suhu $100^{\circ} \mathrm{C}$ selama 1 jam untuk mengurangi kadar air yang ada di dalam kulit durian sehingga tidak membusuk.

\section{Proses Karbonisasi}

Karbonisasi dilakukan menggunakan tanur (furnace) dengan suhu $320^{\circ} \mathrm{C}$ selama 2 jam, kemudian arang didinginkan dengan cara didiamkan ke dalam desikator \pm 15 menit. Arang kemudian dihaluskan dan diayak menggunakan mesh ukuran 70.

\section{Proses Aktivasi}

Pada proses ini $\mathrm{NaOH}$ digunakan sebagai bahan pengaktif. Arang yang telah diayak 
diambil sebanyak 25 gram untuk direndam didalam $250 \mathrm{~mL}$ larutan $\mathrm{NaOH}(0 \%, 25 \%, 30 \%$, dan $35 \%$ ) selama 24 jam, kemudian disaring dengan kertas saring. Arang yang telah diaktivasi, kemudian dicuci dengan aquades hingga $\mathrm{pH}$ netral, dan arang dikeringkan pada suhu $120^{\circ} \mathrm{C}$ selama 30 menit, perlakuan ini dilakukan berulang selama 7 hari.

\section{Pengujian Karakterisasi Arang Aktif Rendemen}

Penetapan rendemen arang aktif dilakukan dengan menghitung perbandingan massa arang aktif yang dihasilkan dengan berat bahan baku yang digunakan.

Rendemen dihitung berdasarkan rumus:

$\%$ Rendemen $=\frac{\text { berat arang aktif }}{\text { berat bahan }} \times 100 \%$

\section{Kadar Air}

Sebanyak 1 gram arang dimasukkan ke dalam cawan yang telah diketahui massanya kemudian dikeringkan dalam oven pada suhu $(103 \pm 2)^{\circ} \mathrm{C}$ selama 3 jam. Kemudian dimasukkan ke dalam desikator hingga bobotnya tetap dan ditentukan kadar air dalam persen (\%). Kadar air arang yang didapatkan, dihitung dengan rumus sebagai berikut:

$\operatorname{Kadarair}(\%)=\frac{\text { BeratAwal }(g)-\text { BeratKering Oven }(g) x 100 \%}{\text { BeratKeringOven }}$

\section{Kadar Abu}

Sebanyak 1 gram arang aktif di masukkan ke dalam cawan yang telah diketahui massanya kemudian diletakkan ke dalam tanur, yang secara perlahan-lahan dipanaskan mulai dari suhu kamar sampai $600^{\circ} \mathrm{C}$ selama 6 jam. Selanjutnya didinginkan dalam desikator sampai massanya konstan, kemudian ditimbang bobotnya. Kadar abu arang dapat dihitung dengan menggunakan rumus sebagai berikut:

$\%$ Kadar $A b u=\frac{W 2-W 0}{W 1-W 0} \times 100 \%$

\section{Daya Serap Iod}

Sampel uji arang aktif dikeringkan menggunakan oven kemudian ditimbang sebanyak 0,25 g kemudian dimasukkan ke dalam labu erlenmeyer. Larutan yodium sebanyak 25 $\mathrm{mL}$ diambil menggunakan propipet dan dimasukkan ke dalam erlenmeyer yang telah terdapat sampel, larutan diaduk menggunakan stirer selama 15 menit. Larutan kemudian disaring menggunakan kertas saring, dan filtrat yang di dapat dipindahkan sebanyak $10 \mathrm{~mL}$ ke dalam erlenmeyer yang berbeda untuk dititrasi menggunakan larutan $\mathrm{Na}_{2} \mathrm{~S}_{2} \mathrm{O}_{3}$. Titrasi dilakukan hingga larutan berubah menjadi warna kuning bening. Kemudian diberikan $1 \mathrm{ml}$ amilum $1 \%$ sebagai indikator. Kemudian proses titrasi dilanjutkan hingga warna biru tepat hilang. Volume larutan yang digunakan $\mathrm{Na}_{2} \mathrm{~S}_{2} \mathrm{O}_{3}$ dicatat dan dihitung daya serap arang aktif terhadap iodin dalam $\mathrm{mg} / \mathrm{g}$ menggunakan rumus sebagai berikut:

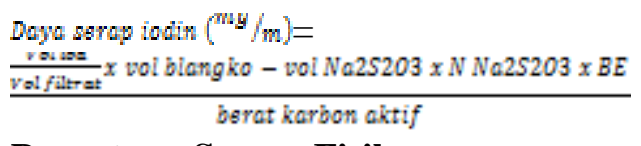

\section{Penentuan Secara Fisika}

\section{Penentuan Kekeruhan}

Sampel air dimasukkan ke dalam botol Turbidimeter hingga tanda batas dan ditunggu selama beberapa menit hingga hasil pengukuran menunjukan angka stabil. Angka yang tertampilkan pada layar Turbidimeter lalu dicatat.

\section{Penentuan Zat Padat Terlarut}

Sampel air dihomogenkan menggunakan vortex, kemudian sebanyak $100 \mathrm{~mL}$ dipindahkan ke gelas beker, TDS meter di masukkan, angka yang muncul kemudian dicatat

\section{Penentuan Secara Kimia}

\section{Penentuan pH}

Sampel air sebanyak $100 \mathrm{~mL}$ dipindahkan ke gelas beker, pH meter di masukkan, angka yang muncul kemudian dicatat.

\section{Proses Adsorpsi Ion Logam Fe (Metode kolorimetri)}

Dua buah tabung reaksi diisi sampel air sebanyak $5 \mathrm{~mL}$. Salah satu tabung reaksi menggunakan pereaksi Fe ditetesi sebanyak 3 tetes. Tabung di tutup lalu digojok agar merata dan kemudian didiamkan selama 3 menit. Warna isi tabung yang muncul dibandingkan di atas papan pembanding kemudian dibandingkan warna yang sama (hampir sama) antara contoh yang diberi pereaksi dengan tabung yang tidak 
diberi pereaksi, nilai kandungan $\mathrm{Fe}$ dari sampel air dicatat.

\section{Pengukuran kesadahan (Metode Titrasi kompleksometri)}

Sampel air sebanyak $25 \mathrm{~mL}$ menggunakan pipet dimasukkan ke dalam Erlenmeyer kemudian ditambahkan $1 \mathrm{~mL}$ larutan buffer pH10.Bila larutan berubah menjadi keruh ditambahkan larutan KCN 10\% sebanyak $1 \mathrm{ml}$. Larutan kemudian ditambahkan sedikit indikator EBT. Larutan yang sudah berubah warna kemudian di titrasi menggunakan larutan EDTA $1 / 28 \mathrm{~N}$ hingga berubah warna dari merah muda menjadi biru, hasil yang didapat dihitung dengan rumus:

\section{Kesadahan Total ( $Q D=$}

$\frac{\left(\frac{3000}{\text { Wal } \operatorname{sem} l k}\right) x \text { Vol EDTA } x \frac{1}{z x} x \text { Faktor EDTA } x 28}{10}$

\section{Penentuan Secara Biologi}

\section{Uji Pendugaan (Presumtive test)}

Sebanyak $0,1 \mathrm{~mL}$ sampel air tanpa perlakuan, kontrol, dan dengan perlakuan masing-masing dimasukkan ke dalam 3 medium LB (lactose broth) yang sudah dilengkapi tabung Durham yang dipasang terbalik pada setiap tabung yang berbeda. Selanjutnya, diinkubasi pada suhu $37^{\circ} \mathrm{C}$ selama 48 jam.Perubahan yang terjadi pada setiap medium diamati dan dicatat, hasil positif (medium warna kuning dan ada gelembung) yang diperoleh digunakan pada uji penetapan

\section{Uji Konfirmasi (Convirmative Test)}

Pada uji ini menggunakan medium BGLB (Brillian Green Lactose Broth). Pada tabung LB (pada uji pendugaan) yang positif diambil 1 ose kemudian diinokulasi pada tabung reaksi yang berisi $10 \mathrm{ml}$ medium BGLB yang telah dipasang tabung Durham. Tabung di inkubasi pada suhu $37^{\circ} \mathrm{C}$ selama 2 hari. Hasil positif dapat terlihat dengan terjadi perubahan warna menjadi pucat/keruh serta terbentuknya gas/gelembung pada tabung Durham. Hasil positif yang terlihat pada tahapan uji ini kemudian dibandingkan pada tabel MPN seri 3 tabung.

\section{Uji Lengkap (Complete Test)}

Sampel hasil positif uji pendugaan diinokulasikan pada medium agar Eosin Methylene Blue menggunakan ose dengan metode streak plate di dalam LAF, kemudian diinkubasi pada suhu $37^{\circ} \mathrm{C}$ selama 48 jam. Hasil yang diperoleh dilakukan pengamatan pertumbuhan koloni dan warnanya. Reaksi positif ditunjukkan dengan warna pink di sekitar medium koloni dan di bagian pinggir koloni serta terbentuk koloni warna metalik pada EMB (Eosin Methylen Blue) agar.

\section{Hasil dan Pembahasan}

\section{Pembuatan Arang Aktif}

Pembuatan arang aktif menggunakan kulit durian yang dipotong kemudian dibakar menggunakan furnace didapatkan ratarata rendemen sebesar 20, 43\%. Rendahnya rendemen arang dikarenakan reaksi antara karbon dengan uap air semakin meningkat dengan bertambahnya suhu dan lamanya waktu karbonisasi, sehingga karbon yang bereaksi menjadi $\mathrm{CO}_{2}$ dan $\mathrm{H}_{2}$ menjadi banyak, sebaliknya jumlah karbon yang dihasilkan semakin sedikit (Pari, 2000).

Tabel 1. Data Uji Kualitas Arang

\begin{tabular}{cccccc}
\hline \hline Perlakuan & $\mathbf{k}$ & $\mathbf{2 5}$ & $\mathbf{3 0}$ & $\mathbf{3 5}$ & SNI \\
\hline \hline \% Kadar Air & $2,71 \%^{\mathrm{h}}$ & $3 \%^{\mathrm{h}}$ & $2,33 \%^{\mathrm{h}}$ & $2.22 \%^{\mathrm{h}}$ & $<15 \%$ \\
\% kadar abu & $3,96 \%^{\mathrm{I}}$ & $4,26 \%^{\mathrm{I}}$ & $4,21 \%^{\mathrm{I}}$ & $4,27 \%^{\mathrm{I}}$ & $<10 \%$ \\
Daya Serap Iod & $717,04^{\mathrm{a}}$ & $736,08^{\mathrm{c}}$ & $761,46^{\mathrm{b}}$ & $774,151^{\mathrm{b}}$ & $>750$ \\
\hline \hline
\end{tabular}

Keterangan : Angka yang diikuti dengan huruf yang sama pada baris yang sama menunjukkan tidak beda nyata, dengan tingkat kepercayaan $95 \%$. 


\section{Uji Kualitas Arang}

Untuk mengetahui mutu arang aktif yang dihasilkan, maka dilakukan uji banding dengan karakterisasi arang menurut SNI 06 - 3730 1995 tentang arang aktif. Hasil uji kualitas arang aktif dapat dilihat pada Tabel 1 .

\section{Penentuan Kadar Air Arang Aktif Kulit Durian}

Penentuan kadar air bertujuan untuk mengetahui sifat higroskopis dari arang aktif yang dihasilkan. Menurut Standar Nasional Indonesia, SNI SNI 06 - 3730 - 1995 dengan persyaratan kadar air yaitu maksimal 15\%, sedangkan kadar air dari arang aktif yang dibuat didapatkan hasil sebesar 2,22\% hingga 3\%. Hal ini menunjukan bahwa arang aktif yang didapatkan untuk parameter kadar airnya sudah memenuhi SNI. Kadar air pada arang aktif dipengaruhi oleh sifat higroskopis dari arang aktif dan jumlah uap air di udara, lama proses pendinginan, penggilingan dan pengayakan (Rosalina dkk., 2016).

\section{Penentuan Kadar Abu Arang Aktif Kulit Durian}

Kadar abu pada arang aktif bertujuan untuk mengetahui kandungan oksida logam yang ada pada arang aktif.Kadar abu arang aktif merupakan sisa yang tertinggal pada saat arang dibakar. Menurut Standar Nasional Indonesia, SNI 06 - 3730 - 1995 dengan persyaratan kadar abu yaitu maksimal $10 \%$, sedangkan kadar abu dari arang aktif yang dibuat didapatkan hasil sebesar $3.96 \%$ hingga $4.27 \%$. Hal ini menunjukkan bahwa arang aktif yang didapatkan untuk parameter kadar abu sudah memenuhi SNI. Hal ini membuktikan bahwa semakin meningkatnya suhu dan waktu karbonisasi maka kadar abu akan semakin tinggi.

\section{Penentuan Daya Serap Iod Arang Aktif Kulit Durian}

Penetapan daya serap arang aktif terhadap daya serap iodium bertujuan untuk mengetahui kemampuan arang aktif untuk menyerap larutan berwarna, dan berbau. Pada SNI No.06-37301995 dengan persyaratan minimal sebesar 750 . Dari data hasil uji daya serap iodin dapat diketahui bahwa pada arang tanpa perlakuan (kontrol) didapatkan hasil sebesar 717,04; pada arang perlakuan dengan aktivasi $\mathrm{NaOH} 25 \%$ didapatkan daya serap iodin sebesar 736,078; pada arang perlakuan dengan aktivasi $\mathrm{NaOH}$ $30 \%$ didapatkan daya serap iodin sebesar 761,46 ; dan pada arang perlakuan dengan aktivasi $\mathrm{NaOH}$ $35 \%$ didapatkan daya serap iodin sebesar 774,151 . Sehingga dapat dikatakan bahwa arang dengan aktivasi $\mathrm{NaOH} 30 \%$ dan 35\% sudah sesuai dengan standar baku. Sedangkan pada perlakuan kontrol dan perlakuan dengan aktivasi $\mathrm{NaOH} 25 \%$ masih belum memenuhi standar baku arang aktif pada SNI. Daya serap iod juga dipengaruhi oleh waktu aktivasi dan rasio aktivator, semakin besar konsentrasi aktivatornya, maka akan semakin besar pula daya serap iodiumnya (Jamilatun dan Setyawan, 2014).

\section{Uji Kualitas Air}

Untuk mengetahui mutu kualitas air yang dihasilkan, maka dilakukan uji banding dengan karakterisasi air menurut Permenkes No 32. tentang standar baku mutu kesehatan lingkungan dan persyaratan kesehatan air untuk keperluan higiene sanitasi. Hasil uji kualitas air terdapat pada Tabel 2.

Tabel 2. Karakteristik Air Sebelum dan Sesudah Perlakuan

\begin{tabular}{|c|c|c|c|c|c|c|}
\hline \multirow{2}{*}{ Perlakuan } & \multirow{2}{*}{$\begin{array}{c}\text { Sebelum } \\
\text { Perlakuan } \\
\end{array}$} & \multicolumn{4}{|c|}{ Sesudah Perlakuan } & \multirow{2}{*}{$\begin{array}{c}\text { Permenkes no } \\
32\end{array}$} \\
\hline & & $\mathbf{K}$ & 25 & 30 & 35 & \\
\hline$\overline{\mathrm{phH}}$ & 6,80 & $\overline{77,10}$ & $\overline{77,16}$ & $\overline{77,11}$ & $\overline{77,09}$ & $6.5-8.5$ \\
\hline $\begin{array}{l}\text { Kekeruhan } \\
\text { (NTUs) }\end{array}$ & $4.876^{\mathrm{h}}$ & $0.52^{\mathrm{g}}$ & $0.29^{\mathrm{g}}$ & $0.24^{\mathrm{g}}$ & $0.22^{\mathrm{g}}$ & $<25$ \\
\hline TDS (ppm) & $287^{\mathrm{e}}$ & $219^{\mathrm{d}}$ & $209^{c}$ & $206^{\mathrm{b}}$ & $203^{\mathrm{a}}$ & $<1000$ \\
\hline Warna & Keruh & Bening & Bening & Bening & Bening & Bening \\
\hline $\mathrm{Bau}$ & $\begin{array}{c}\text { Barbau (bau } \\
\text { besi) }\end{array}$ & $\begin{array}{c}\text { Tidak } \\
\text { Berbau } \\
\end{array}$ & $\begin{array}{c}\text { Tidak } \\
\text { Berbau } \\
\end{array}$ & $\begin{array}{c}\text { Tidak } \\
\text { Berbau } \\
\end{array}$ & $\begin{array}{c}\text { Tidak } \\
\text { Berbau } \\
\end{array}$ & Tidak Berbau \\
\hline
\end{tabular}

Keterangan: Angka yang diikuti dengan huruf yang sama pada baris yang sama menunjukkan tidak beda nyata, dengan tingkat kepercayaan $95 \%$. 


\section{Penentuan Kekeruhan}

Pada pengujian tingkat kekeruhan didapatkan hasil sebelum perlakuan sebesar 4,876 NTU (Nephelometric Turbidity Unit), kemudian sampel disaring menggunakan arang aktif dengan berbagai perlakuan dan didapatkan hasil pada sampel dengan aktivasi $\mathrm{NaOH} 0 \%$ sebesar $0.52 \mathrm{NTU}$, dengan aktivasi $\mathrm{NaOH} 25 \%$ sebesar 0,29 NTU, dengan aktivasi $\mathrm{NaOH} 30 \%$ sebesar 0,24 NTU, dan dengan aktivasi $\mathrm{NaOH}$ $35 \%$ didapatkan hasil sebesar 0,22 NTU. Dapat disimpulkan bahwa arang aktif mampu mengurangi tinggkat kekeruhan $89 \%$ hingga 95\%. Hal ini sesuai hasil penelitian Noer dkk. (2015) yang menjelaskan bahwa kadar aktivator $(\mathrm{NaOH})$ yang digunakan untuk mengaktifkan arang semakin tinggi akan mampu menghasilkan kemampuan adsopsi yang semakin baik, karena aktivator $\mathrm{NaOH}$ mampu memperbesar ukuran pori dan memperbanyak jumlah pori pada arang aktif.

\section{Penentuan Zat Padat Terlarut}

Pada pengujian zat padat terlarut (Total Dissolved Solid) didapatkan hasil sebelum perlakuan sebesar 287, yang kemudian dilakukan perlakuan dengan arang perlakuan kontrol didapatkan hasil 219, dengan perlakuan arang perlakuan $\mathrm{NaOH} 25 \%$ didapatkan hasil 209, dengan arang perlakuan 30\% didapatkan hasil 206, perlakuan dengan arang perlakuan 35 didapatkan hasil 203. Angka pada uji TDS terlihat mengalami penurunan dari sebelum perlakuan dan sesudah perlakuan.

\section{Penentuan pH}

Dari pH sebelum perlakuan didapatkan hasil sebesar 6,80; pada perlakuan kontrol didapatkan $\mathrm{pH}$ sebesar 7,10; pada perlakuan dengan aktivasi $\mathrm{NaOH} 25 \%$ didapatkan $\mathrm{pH} 7,16$; pada perlakuan dengan aktivasi $\mathrm{NaOH} 30 \%$ didapatkan $\mathrm{pH} 7,11$; dan pada perlakuan dengan aktivasi $\mathrm{NaOH} 35 \%$ didapatkan $\mathrm{pH}$ sebesar 7,09. Angka yang ditunjukkan pada $\mathrm{pH}$ meter masih sesuai baku mutu kesehatan media air untuk keperluan higiene sanitasi sesuai MenKes (2017) yaitu 6,5 hingga 8,5 .

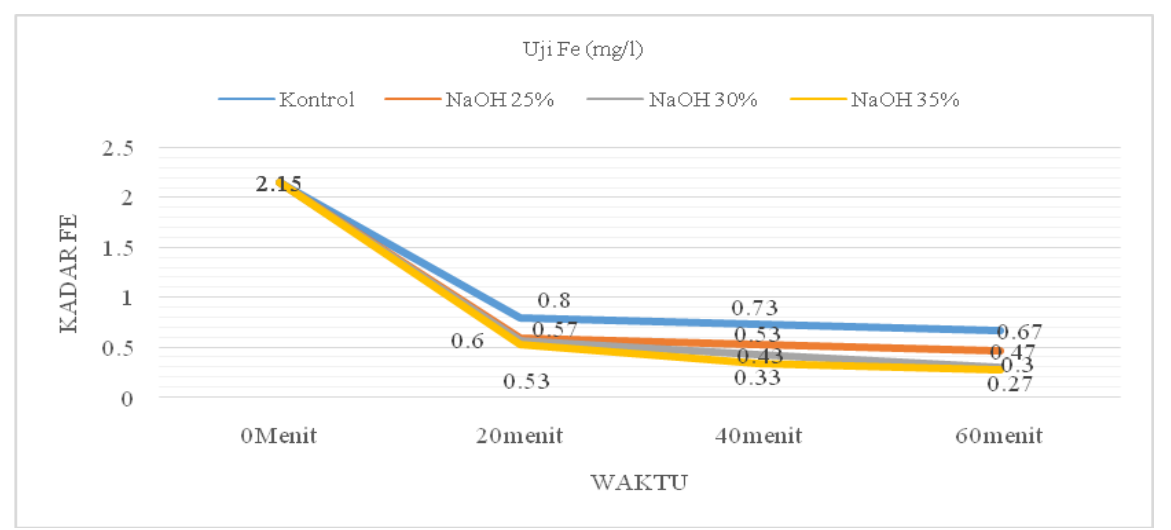

Gambar 1. Adsorpsi Logam Fe Sumur Dengan Arang Aktif

\section{Proses Adsorpsi Ion Logam Fe (Metode Kolorimetri)}

Dari hasil uji kadar Fe pada air sumur (Gambar 1), sebelum diberi perlakuan didapatkan kadar Fe sebesar 2,15 mg/l kemudian dilakukan berbagai perlakuan yaitu dengan perendaman serta pengadukan secara terus menerus. Pada seluruh perlakuan yang dilakukan didapatkan hasil bahwa arang aktif mampu menyerap logam Fe. Berdasarkan analisis statistik yang telah dilakukan disimpulkan bahwa untuk mengadsorpsi logam $\mathrm{Fe}$, arang aktif dengan aktivator $\mathrm{NaOH} 35 \%$ dengan waktu 60 menit merupakan arang aktif yang paling baik dari pada arang aktif dengan aktivator $\mathrm{NaOH} 0 \%$ hingga $30 \%$. Hasil yang didapat menunjukan bahwa semakin tinggi kadar aktivator yang digunakan untuk mengaktifkan arang 
menghasilkan kemampuan adsopsi yang semakin baik, hal ini dikarenakan $\mathrm{NaOH}$ mampu memperbesar ukuran pori dan memperbanyak jumlah pori pada arang aktif seiring dengan peningkatan konsentrasi, sehingga logam $\mathrm{Fe}$ dapat teradsorpsi semakin banyak seiring banyaknya jumlah pori pada arang. Semakin lama kontak arang aktif dengan sampel maka kemampuan untuk menurunkan kadar semakin baik (Noer dkk., 2015), (Jamilatun dan Setyawan, 2014).

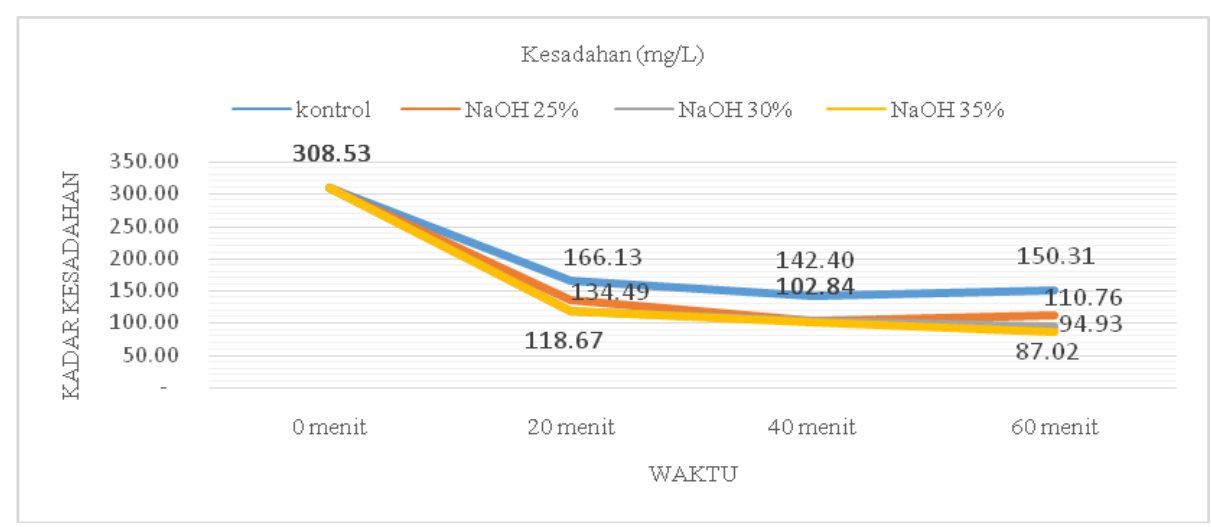

Gambar 2. Kesadahan Air Sumur Dengan Arang Aktif

\section{Pengukuran Kesadahan (Metode Titrasi Kompleksometri)}

Didapatkan hasil kesadahan yang dapat dilihat pada Gambar 2. Pada perlakuan menggunakan arang aktif terlihat bahwa arang aktif mampu mengurangi kesadahan pada air sumur, namun untuk arang aktif yang diaktivasi menggunakan $\mathrm{NaOH}$ dengan konsentrasi $0 \%$ dan $25 \%$ didapati hasil yang naik, hal ini dapat disebabkan dikarenakan arang aktif yang digunakan sudah jenuh dan telah mencapai kapasitasnya. Menurut Wijayanti (2009), bila semua sisi aktif karbon terisi oleh kontaminan, media menjadi jenuh dan telah mencapai kapasitasnya. Pada saat seperti itu kontaminan tidak dapat lagi dijerap atau mungkin beberapa kontaminan terlepas kembali ke dalam air.

\section{Uji Kualitas Air Secara Biologi}

Didapatkan hasil uji koliform yang dapat dilihat pada Tabel 3 .

Tabel 3. Hasil Uji Koliform Air Sumur Setelah Perlakuan Arang Aktif

\begin{tabular}{cccccc}
\hline \multirow{2}{*}{ Perlakuan } & Tabung & MPN per & \multicolumn{2}{c}{ Conf. Lim } & Permenkes no 32 \\
\cline { 4 - 5 } & positif & g/100ml & Terendah & Tertinggi & \\
\hline \hline Tanpa Perlakuan & 333 & 1100 & 420 & 4000 & \\
Kontrol & 330 & 240 & 42 & 1000 & 50 \\
$\mathrm{NaOH} 25 \%$ & 222 & 35 & 8,7 & 94 & \\
$\mathrm{NaOH} 30 \%$ & 231 & 36 & 8,7 & 94 & \\
$\mathrm{NaOH} 35 \%$ & 120 & 11 & 3,6 & 42 & \\
\hline \hline
\end{tabular}

Sampel air sumur masih perlu diolah sebelum dikonsumsi dikarenakan MPN yang cukup tinggi, namun setelah diolah didapatkan bahwa terjadi penurunan kadar koliform dalam air tersebut dan sudah mampu dikatakan bahwa sesuai standar baku mutu yaitu maksimal 50 CFU/100ml (Menkes, 2017). Arang aktif dapat menurunkan MPN koliform sebesar 95,8\%. (Teddy dkk. 2014). Arang aktif menggunakan prinsip dan mekanisme dari adsorpsi yang memungkinkan untuk mengurangi koliform. Arang aktif memiliki sejumlah sifat kimia maupun fisika yang menarik, di antaranya mampu menyerap zat organik maupun anorganik, (Mifbakhuddin, 2010). 


\section{Simpulan dan Saran}

\section{Simpulan}

Berdasarkan hasil penelitian yang telah dilakukan, diperoleh beberapa:

1. Keefektifan arang aktif dari kulit durian untuk proses penjernihan air dalam penurunan kadar $\mathrm{Fe}$ dengan penambahan arang aktif dari kulit durian yang diaktivasi dengan $\mathrm{NaOH}$ adalah sebesar $62,79 \%$ hingga 87,44\% pada waktu 20 hingga 60 menit. Dalam penurunan kadar kesadahan dari $46,15 \%$ hingga $71.80 \%$ pada waktu 20 hingga 60 menit. Dalam menurunkan kadar koliform dari >1100 MPN/100ml menjadi $11 \mathrm{MPN} / 100 \mathrm{ml}$.

2. Konsentrasi aktivator $\mathrm{NaOH}$ yang paling optimal dalam menjernihkan air sumur adalah 35\% dilihat dari hasil analisis kimia dan biologi dalam menurunkan kadar $\mathrm{Fe}$ serta kesadahan dan koliform.

3. Waktu yang paling efektif untuk arang aktif menjernihkan 1 liter air adalah 60 menit.

\section{Saran}

1. Dilakukan pencampuran dalam proses filtrasi menggunakan bahan alam seperti zeolite, pasir untuk mengetahui manfaat secara maksimal dalam menjernihkan air sumur.

2. Uji adsorpsi logam lain untuk mengetahui efektivitas dari kulit durian yang diolah menjadi arang aktif dengan bantuan $\mathrm{NaOH}$.

\section{Daftar Pustaka}

Asmaningrum, H.P., dan Pasaribu, Y.P. 2016. Penentuan Kadar Besi (Fe) dan Kesadahan Pada Air Minum Isi Ulang di Distrik Merauke. Jurnal MAGISTRA 3(2):95-104.

Dantje, T., dan Sembel, B. 2015.Toksikologi Lingkungan. Penerbit Andi, Yogyakarta.

Jamilatun, S., dan Setyawan, M. 2014.Pembuatan Arang Aktif dari Tempurung Kelapa dan Aplikasinya untuk Penjernihan Asap Cair.Jurnal Spektrum Industri 12(1): 1-112.

Lempang, M. 2014. Pembuatan dan Kegunaan Arang Aktif.Jurnal Info Teknis EBONI 11 (2): 65-80.
Marlinawati, Yusuf, B., dan Alimuddin. 2015. Pemanfaatan Arang Aktif dari Kulit Durian (Durio zibethinus L.) sebagai Adsorben Ion Logam Cadmium (II). Jurnal Kimia FMIPA Unmul 13(1): 23-27.

MenKes. 2017. Peraturan Menteri Kesehatan Nomor32 Tentang Standar Baku Mutu Kesehatan Lingkungan Dan Persyaratan Kesehatan Air Untuk Keperluan Hygiene Sanitasi, Kolam Renang, Solus Per Aqua, dan Pemandian Umum. Menteri Kesehatan Republik Indonesia, Jakarta.

Mifbakhuddin, 2010. Pengaruh Ketebalan Karbon Aktif sebagai Media Filter Terhadap Penurunan Kesadahan Air Sumur Artetis. Jurnal Eksplanasi 5 (2): 1-12.

Noer, S., Pratiwi, D.R., dan Gresinta, E. 2015.Pemanfaatan Kulit Durian sebagai Adsorben Biodegradable Limbah Domestik Cair.Jurnal Faktor Exacta 8 (1): 75-78.

Pari, G. 2000. Pembuatan Arang Aktif dari Batubara. Jurnal Buletin Penelitian Hasil Hutan. 17(4): 220-230.

Rosalina, Tedja, T., Riani, E., dan Sugiarti, S. 2016. Pengaruh Aktivasi Fisika dan Kimia Arang Aktif Buah Bintaro Terhadap Daya Serap Logam Berat Krom. Jurnal Biopropal Industri 7(1): 35-45.

Sobir dan Rodame, M.N. 2010. Bertanam Durian Unggul. Penebar Swadaya, Jakarta.

Teddy, B., Suprapto, dan Ginting, M. 2014. Pengaruh Waktu Kontak Air Payau dalam Saringan Pasir dan Arang Kayu Terhadap Penurunan Jumlah Bakteri Coli-Form, Kekeruhan dan Salinitas untuk Kebutuhan Air Minum. Jurnal Ilmiah Pannmed 8(3): 218-228.

Untung, O. 2008. Menjernihkan Air Kotor. Puspa Swara, Jakarta.

Wijayanti, R. 2009. Arang Aktif dari Ampas Tebu Sebagai Adsorben Pada Pemurnian Minyak Goreng Bekas. Skripsi. Tidak Diterbitkan. Fakultas Matematika dan Ilmu Pengetahuan Alam. Institut Pertanian Bogor, Bogor. 